\title{
Genome dynamics, genetic complexity and macroevolution
}

\author{
Dinámica del genoma, complejidad genética y macroevolución
}

\author{
MILTON H. GALLARDO
}

Instituto de Ecología y Evolución, Universidad Austral de Chile, Casilla 567, Valdivia, Chile; e-mail mgallard@uach.cl

\begin{abstract}
Genome data analysis indicates that the major evolutionary transitions have been driven by substantial increases in genomic complexity. These increases, accounting for novelty in evolution, have proceeded mainly by gene duplication. This idea, advanced by Ohno (1968), remains current in the study of several organisms whose genomes have been sequenced. Maize, yeast, and humans contain more paralogons than would be expected to occur by chance, and this supports the contention that gene families were not formed de novo, but by large-scale DNA duplications. Lineage hybridization emerges as an efficient and widespread mechanism to create evolutionary novelty by recruiting redundant genes to new roles. Lateral gene transfer indicates a chimeric composition of prokaryote genomes. This peculiar manner of inheritance blurs the edges of phylogenetic lineages and suggests that the anastomosing and dichotomization of branches play key roles in determining the shape of the tree of life. Adaptive mutations have also enlarged the genetic framework of evolutionary thought by incorporating a new mechanism of gene formation. Moreover, developmental biology has provided solid grounds for understanding organisms as consisting of onto- and epigenetically organized modules. Rapid and drastic changes brought about by the study of developmental genes have discredited the notions that adaptation is achieved exclusively by stepwise allele replacement within populations, and that macroevolutionary change is extrapolated microevolution. Apparently, a broadening, if not a remodeling of the genetic framework in which we understand phylogeny and the evolution of morphological complexity, is emerging through the study of comparative genomics.
\end{abstract}

Key words: gene duplication, genome, genetics, evolution, macroevolution, evolutionary theory.

\section{RESUMEN}

El análisis genómico comparado indica que las principales transiciones evolutivas se deben a un aumento de la complejidad genómica. Estos incrementos que dan cuenta de las novedades evolutivas se han originado principalmente por duplicaciones génicas. Esta idea, desarrollada por Ohno (1968) permanece vigente en el estudio de varios organismos cuyos genomas se han secuenciado. El maíz, la levadura y los humanos contienen más paralogones que lo esperado por azar, apoyando así la idea que las familias génicas no se formaron de novo, sino por duplicaciones a gran escala del ADN. La hibridización de linajes emerge como un mecanismo eficiente y diseminado que crea novedades evolutivas por reclutamiento de genes redundantes hacia nuevos roles. La transferencia génica lateral indica una composición quimérica de los genomas de procariontes. Esta peculiar forma de herencia oscurece los límites de los linajes filogenéticos y sugiere anastomización y dicotomización en la forma del árbol de la vida. Las mutaciones adaptativas también han ensanchado el marco genético del pensamiento evolutivo al incorporar un nuevo mecanismo de formación de genes. Además, la biología del desarrollo ha entregado evidencias sólidas de la organización modular onto- y epigenética del organismo. Los cambios rápidos y drásticos generados por los genes del desarrollo han falseado la noción que la adaptación se logra exclusivamente por el reemplazo gradual de alelos, y que el cambio macroevolutivo es microevolución expandida. Con todo, la genómica comparada parece estar gestando una ampliación o un remodelamiento del marco genético en que comprendemos la filogenia y la evolución de la complejidad morfológica.

Palabras clave: duplicación génica, genoma, genética, evolución, macroevolución, teoría evolutiva.

\section{INTRODUCTION}

\section{The prokaryote's complexity}

Bacterial genomes have been demonstrated to possess such a wealth of genetic diversity that two of the three urdomains (Archaea and Eubacteria) consist of prokaryotes (Woese 1987). The genetic distinctiveness of prokaryotes is surprising, as is the peculiar mechanism of hereditary transmission known as lateral gene transfer (LGT). This new 
mechanism, allows organisms to acquire heritable traits across mating barriers and regardless of phylogenetic proximity (Ravi et al. 1999, De la Cruz \& Davies 2000). Unlike the traditional Mendelian view based on vertical gene transmission, archaeal genomes indicate that LGT and subsequent divergence has occurred repeatedly at the base of the tree of life (Anderson \& Anderson 1999, Itaya 1999). The endosymbiotic origin of mitochondria and chloroplasts in eukaryotic cells is a classic example of LGT in evolution (Margulis \& Dolan 2002). The 234 events of introgression between the genomes of $E$. coli and Salmonella enterica (Marienfeld et al. 1999) and the transference of the catalaseperoxidase genes between the Archaea and pathogenic Bacillus subtilis are also cases in point (Itaya 1999, Faguy \& Doolittle 2000). LGT can also result from the dynamics of mobile genetic elements and can be responsible for the pathogenecity and antibiotic resistance in bacteria, and for DNA transference between Drosophila species (Brown 2003). Some estimates suggest that 1.6 to $9.2 \%$ of Arabidopsis nuclear genes involved in biosynthetic, housekeeping, and catabolic functions were transferred from cyanobacteria (Doolittle 1999b, Marienfeld et al. 1999). Recent data not only recognize LGT as a widespread phenomenon in flowering plants, but also as the main driving force of the evolution of cellular life (Bergthorsson et al. 2003, Brown 2003).

LGT can lead to such a widespread propagation of transpecific innovations that it distorts phylogenetic reconstructions, since homologous features present in the descendant lineage may have not been present in the ancestors (Gogarten \& Olendzenski 1999). By incorporating foreign genes into a genome, LGT has introduced another variable in phylogenetic reconstruction, namely, xenology. As a consequence, some authors have considered idealistic to seek a molecular classification based exclusively on the genealogical component of genetic differentiation. Apparently, the history of life resembles a bush of anastomosing branches; not a dichotomizing tree (Doolittle 1999a, 1999b).

The question concerning the evolutionary role of mutations has become more complex and controversial with the discovery of adaptive mutations (Foster 1999, Rosenberg 2001). For a mutation to be adaptive, it must arise rapidly in a static population subjected to a nonlethal selective pressure (Foster 1998). The term adaptive was used to indicate an organismic response to an environment in which the mutations were selected. While, for some authors, adaptive mutations do not constitute a mechanism but a strategy (Foster 1998), for others it casts evolution and heredity into a new perspective for its Lamarckian implication (Rosenberg 2001). Undoubtedly, these findings not only complicate the task of constructing the tree of life, but cast doubts upon the assertion that mutations are exclusively random events (Brisson 2003). The challenge will be to distinguish noise from signal in the years to come.

\section{THE CREATIVE DYNAMICS OF GENOMIC REDUNDANCY IN EUKARYOTES}

Genome size has followed very complex patterns of evolution as inferred from the differences in DNA content among organisms (Li 1997, Ruddle 1997, Gregory \& Hebert 1999). Although constant within a species, intertaxa variation in genome size is not directly related to the organism's degree of morphophysiological complexity (Bennet 1982). This decoupling, known as the $\mathrm{C}$-value paradox has been explained by assuming both a neutral role of non-functional sequences (Sessions \& Larson 1987, Roth et al. 1997), or by invoking an adaptive correlation to environmental challenges (Hughes \& Hughes 1995).

Athough the controversy over the relative importance of gradual/quantum shifts in genome size still persists (Gregory \& Hebert 1999), is it clear that the major evolutionary transitions (from prokaryotes to eukaryotes, from protozoans to metazoans, from radial to bilateral symmetry, and from invertebrates to vertebrates) were driven by genetic redundancy. Instead of natural selection, which was considered the driving force for morphological innovations and metabolic complexity, gene and genome duplications are now coming to be viewed as the main forces behind these developments (Klein et al. 1998, Holland \& Chen 2001, Meyer \& Van de Peer 2003, Zhang 2003). The crucial role of gene and genome duplications not only has affected the origin of novelty in chordates (Holland \& García-Fernández 1996, Holland 1999, Rokas \& Holland 2000) but of eukaryotes as a whole (Spring 2003). The coincidental presence of tetralogs supports polyploidization as the most parsimonious hypothesis to account for the evolution of novelty in vertebrates (Spring 1997, Akam 1998, Amores et al. 1998, Postlethwait et al. 1998, McLysaght et al. 
2002). The four copies of the gene families, zinc finger transcription factors, the MHC (Klein et al. 1998), aldolases, hormones (Offir \& Gootwine 1997, Wallis et al. 1998), and the Hox clusters (Holland \& García-Fernández 1996, Sharman \& Holland 1998, Holland 1999) support this view, since only one copy of some of them is found in invertebrates (Coy et al. 1996, Sharman et al. 1997). The first genome duplication is thought to predate the Cambrian explosion, whereas the second had occurred after the divergence of the actinopterygianssarcopterygian lineages (Meyer \& Schartl 1999, Rokas and Holland 2000). Although some detractors claim that it is not clear how many rounds of polyploidy took place before the origin of the cephalochordates, the role of genome duplications in chordate evolution remains undisputed (Arthur 2002, McLysaght et al. 2002, Spring 2003). The $44 \%$ of paralogons in the human genome further supports the hypothesis of at least one polyploidization event in the evolution of the vertebrate lineage (McLysaght et al. 2002, Hokamp et al. 2003).

The most effective mean of genome duplication is via allopolyploidization (Ohno et al. 1968, Sparrow \& Nauman 1976). Its incidence in evolution can be estimated from the numbers of animal (approximately $1,224,751)$ and plant species $(248,428$; Freeman \& Herron 1998). Keeping in mind that $95 \%$ of the 10,000 species of Pteridophyta, and that $50-70 \%$ of the 220,000 species of angiosperms are polyploids (Soltis \& Soltis 1999), around $48-66 \%$ of the plant species possess duplicated genomes. When all eukaryotes are considered together, between 8 $11 \%$ may have polyploid origins. These figures illustrate the important role of genome duplication as a source of evolutionary novelty (Soltis \& Soltis 1995, 1999, Otto \& Whitton 2000) and stress the adaptive role of tetraploids relative to their diploid ancestors (Ruddle 1997, Gibson \& Spring 1998, Cook \& Soltis 1999).

Within the vertebrates, instances of wholegenome duplications have been found in fishes, amphibians, reptiles (Bogart 1980, Beçak \& Beçak 1998), and mammals (Gallardo et al. 1999). Most examples involve species that either demonstrate a parthenogenetic mode of inheritance (Bogart 1980), lack heteromorphic sex chromosomes, or have a constrained system of sex determination (Tymowska 1991). These contraints probably account for the reduced tendency of animals to form polyploids when compared with plants (Orr 1990). The classical Mullerian explanation for the rarity of polyploid animals stresses fertility and the developmental barriers raised by crosses between diploid ancestors and tetraploid descendants (Orr 1990). Nevertheless, these obstacles are overcome in natural triploids by bizarre instances of parthenogenesis, hybridogenesis, or gynogenesis (Vinogradov et al. 1990, Stöck et al. 2002).

The means by which correct gene dosage and equational chromosome segregation are maintained after genome fusion of different lineages are numerous and complex (Comai 2000). Regardless of life history strategies, genomic adjustments in polyploids regulate the copy number of redundant DNA sequences leading ultimately to functional or structural diploidization (Leipoldt 1983, Wolfe 2001). For example, different frog species demonstrated to be tetraploid by their DNA content have diploid levels of gene expression (Beçak \& Pueyo 1970, Schmidtke et al. 1976, Ruíz \& Brison 1989), diploidized meiotic behavior (Beçak \& Beçak 1974) and diploid patterns of allozymic variation (Beçak \& Goissis 1971, Schmidtke et al. 1976). Correct gene expression patterns in polyploids is maintained by a flurry of epigenetic events, including DNA methylation and histone acetylation (Meyer \& Schartl 1999, Comai 2000, Pikaard 2001). More drastic adjustments include the elimination of coding and noncoding DNA sequences in ferns (Gastony 1991) and in the angiosperm genera Triticum, Aegilops (Feldman et al. 1997, Liu et al. 1998a, 1998b), and Arabidopsis (Chen et al. 1998).

Preferential pairing of homologous (and homeologous chromosomes) in polyploid plants is another form of structural diploidization that maintain the normal segregation of alleles (Wolfe 2001). Functional and structural diploidization affecting NOR sites occur in the polyploid frog genus Scaphyophryne (Vences et al. 2002), whereas these regions are eliminated in the tetraploid frog Hyla (Mable \& Bogart $1995)$ as well as in the polyploid plant complex Sanguisorba (Mishima et al. 2002). Contrary to the pattern implied by previous ideas, the drastic mechanisms of epigenetic control following polyploidization events get stabilized in few generations (Gastony 1991, Song et al. 1995, Mittelsten-Scheid et al. 1996, Matzke et al. 1999).

After an event of gene duplication, both copies may be retained, be transformed into a pseudogene, or be lost (Seoighe \& Wolfe 1999, Wendel 2000). The retention of both copies may result from selection for redundant gene function (Gibson \& Spring 1998) and co-option 
for a new use in a related developmental pathway (Raff 1996). The realization of the important role of gene duplications in evolution has called attention to the distinction between orthologous genes (having homology of origin, but not necessarily of function) as opposed to paralogous ones (homologues by gene duplication). The need to distinguish between these forms of homology makes phylogenetic reconstruction a more complex task.

\section{DEVELOPMENTAL BIOLOGY AND MACROEVOLUTION}

To fulfill their disparate biological requirements, plant and animal genomes have evolved into unique and sophisticated regulatory networks of functionally interconnected transcriptional pathways (Eulgem et al. 2000). Comparative genomics applied to genes governing developmental processes (i.e., knock-outs, reporter proteins, transgenic embryos) has contributed enormously to understanding the mechanistic processes that control epigenesis, and how these regulatory changes translate into modifications of the animal Bauplan (Wolfe \& Li 2003). Thus, once the genomes acquire larger sizes, the evolution of complex structures results from the elaboration of control mechanisms over the pre-existing genetic machinery (Manzanares et al. 2000). For instance, the macroevolutionary divergence of leaves and reproductive structures in plants arose concomitantly with the emergence of actins and other cytoskeletal proteins not present in the plants' ancestors (Meagher et al. 1999). Regulatory switches, homologous to animal homeotic genes, control the timing of flowering, reproduction, and the identity and differentiation of petals and sepals in plants (Levy \& Dean 1998, Lawton-Rauh et al. 2000). Likewise, the regulation of senescence and the control of pathogen-induced defenses in plants has resulted from reshuffling the functional domains of pre-existing proteins (Eulgem et al. 2000). In this respect, molecular adaptations are directly associated with the number of new gene families, their diversification, and increasing regulatory capabilities.

One of the most far-reaching evolutionary implications of developmental biology is that homeotic genes are highly conserved and interchangeable between organisms that may even belong to different Phyla (Percival-Smith \& Laing-Bondy 1999). It is also clear that relatively small mutations in regulatory pathways may produce dramatic phenotypic consequences identified by their loss-offunction effect (Arthur 2002). For example, the loss of Hox expression in the mandible arches of gnathostomes is associated with the acquisition of jaws in vertebrates (Cohn 2002). Conversely, the rostral overexpression of Hoxb- 8 produces cervical ribs in mice, and it is associated with the animals' susceptibility to the development of leukemia and fibrosarcoma (Galis 1999). Mutations that change the expression of the interacting genes Ultrabithorax and Abdominal-A in different segments transform a walking leg into a feeding appendage in crustaceans or reduce the number of leg-bearing segments between crustaceans and insects (Raff 1996, Gilbert 2000). Likewise, the ectopic expression of some homeotic genes in plants is sufficient to transform a vegetative organ into a floral component (Honma \& Goto 2001). These patterns of spatio-temporal expression exemplify morphological innovations that take place without changes in gene frequency and provide a mechanistic framework for a better understanding of heterochronic, heterotopic, and allometric processes in macroevolution (Finnerty 2000, Manzanares et al. 2000, Arthur 2002). The evolutionary conservancy of these organic codes challenges the classical concept of homology since if the coding DNA sequences and the biochemical pathways leading to a certain feature in two distantlyrelated organisms are the same, the structures should be considered homologous.

The possibility of isolating, cloning, and inserting (or deleting) genes from model organisms has transformed the field of developmental biology into a powerful, explanatory science. The corroboration that ontogeny proceeds through developmental genes and that organisms are genetically organized in modules has overturned some classical tenets (Raff 1996, Arthur 2002). Modules, recognized from cascading signals to body parts, are relatively independent units of development and function (Schlosser \& Thieffry 2000). The deep manifestations of modularity suggest that the reproductive potential of an organism may not be disrupted by morphological changes affecting other modules.

Unfortunately, the way that molecular biologists gather and discuss their data does not help to clarify the philosophical issues raised by comparative genomics. It is not a surprise that the molecular knowledge accumulated during the last decade has revived the design argument and become a challenge against 
evolution at the biochemical level. In relation to the complex biochemical pathways leading to color vision or the cascade of events involved in the blood clotting process, the question is how did these complex and delicately balanced processes evolve since the activation of each protein is interdependent (Hoyle 1983, Behe 1996). This is the argument of intelligent design, and it stems from the reversal of logic. Although Greek thinkers thought that the pattern generated at the end of a sequence of events could be regarded as the cause of the pathways followed by the sequence itself, this does not mean that the effects precede the causes of natural phenomena (Bateson 1979). This reversal of logic leads to the teleological fallacy that end determines process, or to the myth that some supernatural controlling agent has actively designed the fabric of life. When life is seen as a creation, the deduction that there must be a creator of life is inescapable, just as logic dictates that there must be a thinker behind any thought. Although, for molecular biologists, data are thought to speak for themselves in such a way that hypothesis-based research has lost its dominant role, the molecular biologists' endeavours seek explanations by natural causes. The new genetic processes reporting the dynamic nature of genomes and the significance of gene and genome duplications reaffirm the scientists' natural theses but suggest a broader evolutionary framework.

\section{CONCLUDING REMARKS}

Much has been learned by taking this genomic view of life, and new, complex, or conflicting questions are impacting evolutionary theory (Wolfe \& Li 2003). Genome research indicates that prokaryote and eukaryote genomes are highly plastic, dynamic and chimeric. Contrasting with the vertical Mendelian gene transmission, LGT affects the basal branches of the tree of life and suggests that a bush consisting of divergent and convergent branches better define the topological relationships among its three domains (Doolittle 1999a, 1999b). The discovery of adaptive mutations also challenges the classical assertions that mutations occur independently of the environment, that they are rate-constant, and that they occur by replication errors (Brisson 2003). Moreover, the extreme molecular diversity of mitochondrial haplotypes found in tetraploid Bryophyta and Pteridophyta indicates their multiple and independent derivations (Soltis \& Soltis 1999, Otto \&
Whitton 2000), thus challenging the dogma of the monophyletic origin of all species.

Current evolutionary thinking accepts that adaptation is achieved by stepwise selection by means of allele replacement within populations, that speciation is the extrapolated by-product of genetic divergence, and that macroevolutionary phenomena are the extrapolation of microevolutionary changes (Dobzhansky 1970). Nevertheless, 50 years of experimentation have neither demonstrated the effect of disruptive selection on reproductive isolation nor the crucial role of bottlenecks in promoting speciation (Rice \& Hostert 1993). Population genetic models can explain the fate of adaptive traits by analyzing the allelic changes of structural genes through time, but they fail to explain the evolution of morphological features in any biological system. On the contrary, the reproducible studies and the experimental manipulation of developmental genes are reunifying the gap between micro- and macroevolutionary change. Since these mechanistic explanations have drastically changed the way we understand the epigenetic processes, the old idea that "ontogeny creates phylogeny" has been revived (Gilbert 2000). It could be argued, though, that the gene's present regulatory role was not necessarily so in the organism's evolutionary past. But logical as this criticism may be, it cannot be falsified unless the "tape of time" could be played twice (Gould 1989, Fontana \& Buss 1994).

Substantial evidence indicates that gene duplications have played a central role in the evolution of morphological innovations by recruiting copies of previously existing genes to new roles. This suggests that tandem gene duplication or even entire genome duplications are much more common than the de novo origin of genes (Meyer \& Van de Peer 2003). Thus, Ohno's (1968) assertion, that natural selection is merely a modifying force while the creative role seems to belong to gene duplication, rivals in its iconoclastic implications the notion that ontogeny creates phylogeny.

Mayr's (1963) classical view of the organism emphasizes only small and gradual evolutionary changes since the delicate controlling epigenetic changes could hardly be improved by a drastic, saltational change. Nevertheless, the picture emerging from comparative developmental biology indicates that organisms consist of onto- and epigenetically independent modules. Future research will shed more light into this apparent disassociation between morphological change and reproductive isolation. 
Comparative genomics points towards a broader genetic framework for understanding molecular adaptations, organismic architecture, phylogenetic relationships, and macroevolution. Whether or not this newly emerging framework will continue being part of an expanded Neodarwinian tradition or will be further developed into a new scientific paradigm cannot be ascertained at this moment but undoubtedly these recent developments in the study of genome dynamics are shaking the tree of life.

\section{ACKNOWLEDGEMENTS}

This work, dedicated to the memory of Olga Narcisi, was supported by FONDECYT 1010727 to MHG.

\section{LITERATURE CITED}

AKAM M (1998) Hox genes, homeosis and the evolution of segment identity: no need for hopeless monsters. International Journal of Developmental Biology 42: 445-451.

AMORES A, A FORCE, YL YAN, L JOLY, C AMAMIYA, A FRITZ, RK HO, ET AL. (1998) Zebrafish hox clusters and vertebrate genome evolution. Science 282: 1711-1714.

ANDERSON JO \& SG ANDERSON (1999) Insights into the evolutionary process of genome degradation. Current Opinion in Genetics and Development 9: 664-671.

ARTHUR W (2002) The emerging conceptual framework of evolutionary developmental biology. Nature 415 : 757-764.

BATESON G (1979) Mind and nature - a necessary unity. Bantam Books, New York, New York, USA. 259 pp.

BEÇACK ML \& W BEÇAK (1974) Diploidization in Eleutherodactylus (Leptodactylidae-Amphibia). Experientia 30: 624-625.

BEÇAK ML \& W BEÇAK (1998) Evolution by polyploidy in Amphibia: new insigths. Cytogenetics and Cell Genetics 80: 28-33.

BEÇAK W \& G GOISSIS (1971) DNA and RNA content in diploid and tetraploid amphibians. Experientia 15: 345-346.

BEÇAK W \& MT PUEYO (1970) Gene regulation in the polyploid amphibian Odontophrynus americanus. Experimental Cell Research 63: 448-453.

BEHE MJ (1996) Darwin's black box. The biochemical challenge to evolution. Touchstone, New York, New York, USA. 307 pp.

BENNET MD (1982) Nucleotypic basis of the spatial ordering of chromosomes in eukaryotes and the implications of the order for genome evolution and phenotypic variation. In: Dover GA \& RB Flavell (eds) Genome evolution: 239-262. Academic Press, New York, New York, USA.

BERGTHORSSON U, ADAMS KL, THOMASON B \& JD PALMER (2003) Widespread horizontal transfer of mitochondrial genes in flowering plants. Nature 424: 197-201.

BOGART JO (1980) Evolutionay implications of polyploidy in amphibians and reptiles. In: Lewis
WH (ed) Polyploidy: biological relevance: 341-381. Plenum Press, New York, New York, USA.

BRISSON D (2003) The directed mutation controversy in an evolutionary context. Critical Reviews in Microbiology 29:25-35.

BROWN JR (2003) Ancient horizontal gene transfer. Nature Genetics 4: 121-132.

CHEN ZF, COMAI L \& CS PIKAARD (1998) Gene dosage and stochastic effects determine the severity and direction of uniparental ribosomal RNA gene silencing (nuclear dominance) in Arabidopsis allopolyploids. Proceedings of the National Academy of Sciences USA 95: 14891-14896.

COHN MJ (2002) Lamprey Hox genes and the origins of jaws. Nature 416: 386-387.

COMAI L (2000) Genetic and epigenetic interactions in allopolyploid plants. Plant Molecular Biology 43: 387-399.

COOK LM \& PS SOLTIS (1999) Mating systems of diploid and allotetraploid populations of Tragopogon (Asteraceae). I. Natural populations. Heredity 82: 237-244.

COY JF, SP DUBEL, K KIOSCHIS, G THOMAS, H MICKLEM, H DELUIS \& A POUSTKA (1996) Molecular cloning of tissue-specific transcripts of a transketolase-related gene: implications for the evolution of new vertebrate genes. Genomics 32: 309-316.

DE LA CRUZ F \& J DAVIES (2000) Horizontal gene transfer and the origin of species: lessons from bacteria. Trends in Microbiology 8: 128-133.

DOBZHANSKY T (1970) Genetics and the origin of species. Columbia University Press, New York, New York, USA. 364 pp.

DOOLITTLE WF (1999a) Lateral genomics. Trends in Genetics 15: M5-M8.

DOOLITTLE WF (1999b) Phylogenetic classification and the universal tree. Science 284: 2124-2129.

EULGEM T, PJ RUSHTON, S ROBATZEK \& I SOMSSICH (2000) The WRKY superfamily of plant transcription factors. Trends in Plant Science 5: 199-206.

FAGUY DM \& WF DOOLITTLE (2000) Horizontal transfer of catalase-peroxidase genes between Archaea and pathogenic bacteria. Trends in Genetics 16: 196-197.

FELDMAN M, B LIU, G SEGAL, S ABBO, AA LEVY \& JM VEGA (1997) Rapid elimination of low-copy DNA sequences in polyploid wheat: a possible mechanism for differentiation of homoeologous chromosomes. Genetics 147: 1381-1387.

FINNERTY JR (2000) Head start. Nature 408: 778-781.

FONTANA W \& LW BUSS (1994) What would be conserved if "the tape were played twice". Proceedings of the National Academy of Sciences USA 91: 757-761.

FOSTER PL (1998) Adaptive mutation: has the unicorn landed? Genetics 148: 1453-1459.

FOSTER PL (1999) Mechanisms of stationary phase mutation: a decade of adaptive mutation. Annual Review of Ecology and Systematics 33: 57-88.

FREEMAN S \& JC HERRON (1998) Evolutionary analysis. Prentice Hall, Upper Saddle River, New Jersey. $786 \mathrm{pp}$

GALIS F (1999) Why do almost all mammals have seven cervical vertebrae? Developmental constraints, Hox genes, and cancer. Journal of Experimental Zoology 285: $19-26$.

GALLARDO MH, JW BICKHAM, RL HONEYCUTT, RA OJEDA \& N KÖHLER (1999) Discovery of tetraploidy in a mammal. Nature 401: 341 . 
GASTONY GJ (1991) Gene silencing in a polyploid homosporous fern: paleopolyploidy revisited. Proceedings of the National Academy of Sciences USA 88: 1602-1605.

GIBSON TJ \& J SPRING (1998) Genetic redundancy in vertebrates: polyploidy and persistence of gene encoding multidomain proteins. Trends in Genetics 14: 46-49.

GILBERT SF (2000) Developmental biology. Sixth edition. Sinauer Associates, Inc., Publishers, Sunderland, Massachusetts, USA. 749 pp.

GOGARTEN JP \& L OLENDZENSKI (1999) Orthologous, paralogs and genome comparisons. Current Opinion in Genetics \& Development 9: 630-635.

GOULD SJ (1989) Wonderful life: the burguess shale and the nature of history. WW Norton \& Company, New York, New York, USA. 347 pp

GREGORY TR \& PDN HEBERT (1999) The modulation of DNA content: proximate causes and ultimate consequences. Genome Research 9: 317-324.

HOKAMP K, A MCLYSAGHT \& KH WOLFE (2003) The $2 \mathrm{R}$ hypothesis and the human genome sequence. Journal of Structural and Functional Genomics 3 : 95-110.

HOLLAND PWH (1999) The future of evolutionary biology. Nature 402 Supplement C41-C44

HOLLAND PWH \& J GARCÍA-FERNÁNDEZ (1996) Hox genes and chordate evolution. Developmental Biology 173: 382-395

HOLLAND ND \& J CHEN (2001) Origin and early evolution of the vertebrates: new insights in molecular biology, anatomy and paleontology. Bioessays 23: 142-151.

HONMA T \& K GOTO (2001) Complexes of MADS-box proteins are sufficient to convert leaves into floral organs. Nature 409: 525-529.

HOYLE F (1983) The intelligent universe: a new view of creation and evolution. Dorling and Kindersley Limited, London, United Kingdom. 256 pp.

HUGHES AL \& MK HUGHES (1995) Small genomes for better flyers. Nature 377: 391.

ITAYA M (1999) Genetic transfer of large DNA inserts to designated loci of the Bacillus subtilis 168 genome. Journal of Bacteriology 181: 1045-1048.

KLEIN J, A SATO \& C O’HUIGIN (1998) Evolution by gene duplication in the major histocompatibility complex. Cytogenetics and Cell Genetics 80: 123-127.

LAWTON-RAUH AL, ER ÁLVAREZ-BUYLLA \& MD PURUGGANAN (2000) Molecular evolution of flower development. Trends in Ecology and Evolution 15: 144-149.

LEIPOLDT M (1983) Towards an understanding of the molecular mechanisms regulating gene expression during polyploidization in phylogenetically polyploid lower vertebrates. Human Genetics 65: 11-18.

LEVY YY \& C DEAN (1998) Control of flowering time. Current Opinion in Plant Biology 1: 49-54.

LI W-H (1997) Molecular evolution. Sinauer Associates, Inc. Publishers, Cambridge, Massachusetts, USA $487 \mathrm{pp}$

LIU B, JM VEGA, G SEGAL, S ABBO, M RODOVA \& M FELDMAN (1998a) Rapid genomic changes in newly synthesized amphiploids of Triticum and Aegilops. I. changes in low-copy noncoding DNA sequences. Genome 41: 272-277.

LIU B, JM VEGA \& M FELDMAN (1998b) Rapid genomic changes in newly synthesized amphiploids of Triticum and Aegilops. II. changes in low-copy coding DNA sequences. Genome 41: 535-542.
MABLE BK \& JP BOGART (1995) Hybridization between tetraploid and diploid species of treefrogs (genus Hyla). Journal of Heredity 86: 432-440.

MANZANARES $\mathrm{M}, \mathrm{H}$ WADA, $\mathrm{N}$ ITASAKI, PA TRAINOR, R KRUMLAUF \& PWH HOLLAND (2000) Conservation and elaboration of Hox gene regulation during evolution of the vertebrate head. Nature 408: 854-857.

MARIENFELD J, M UNSELD \& A BRENNICKE (1999) The mitochondrial genome of Arabidopsis is composed of both native and immigrant information. Trends in Plant Science 4: 495-502.

MARGULIS A \& MF DOLAN (2002) Early life: evolution on the precambrian earth. Jones and Barlett Publishers, Inc., Sudbury, Massachusetts, USA. 168 pp.

MATZKE MA, O MITTELSTEN \& AJM MATZKE (1999) Rapid structural and epigenetic changes in polyploid and aneuploid genomes. Bioessays 21: 761-767.

MAYR E (1963) Populations, species, and evolution. The Belknap Press of Harvard University Press, Cambridge, Massachusetts, USA. 453 pp.

MCLYSAGHT A, K HOKAMP \& KH WOLFE (2002) Extensive genome duplication during early chordate evolution. Nature Genetics 31: 200-204.

MEAGHER RB, EC MCKINNEY \& AV VITALE (1999) The evolution of new structures: clues from plant cytoskeletal genes. Trends in Genetics 15: 278-284.

MEYER A \& M SCHARTL (1999) Gene and genome duplications in vertebrates: the one-to-four (-toeight in fish) rule and the evolution of novel gene functions. Current Opinion in Cell Biology 11: 699-704.

MEYER A \& Y VAN DE PEER (2003) Natural selection merely modified while redundancy created-Susumu Ohno's idea of the evolutionary importante of gene and genome duplications. Journal of Structural and Functional Genomics 3: vii-ix.

MISHIMA M, N OHMIDO, K FUKOI \& $\mathrm{T}$ YAHARA (2002) Trends in site-number change in rDNA during polyploid evolution in Sanguisorba (Rosaceae). Chromosoma 110: 550-558.

MITTELSTEN-SCHEID O, L JAKOVLEVA, K AFSAR, J MALUSZYNSKA \& J PASZKOWSKI (1996) A change in ploidy can modify epigenetic silencing. Proceedings of the National Academy of Sciences USA 93: 7114-7119.

OFFIR R \& E GOOTWINE (1997) Ovine growth hormone gene duplication. Structural and evolutionary implications. Mammalian Genome 8: 770-772.

OHNO S, U WOLF \& NB ATKIN (1968) Evolution from fish to mammals by gene duplication. Hereditas 59: 169-187.

ORR HA (1990) "Why polyploidy is rarer in animals than in plants" revisited. American Naturalist 136: 759-770.

OTTO SO \& J WHITTON (2000) Polyploid incidence and evolution. Annual Review of Genetics 34: 401-437.

PERCIVAL-SMITH A \& JA LAING BONDY (1999) Analysis of murine HOXA2 activity in Drosophila melanogaster. Developmental Genetics 24: 336-344.

PENNISI E \& W ROUSH (1997) Developing a new view of evolution. Nature 277: 34-37.

PIKAARD CS (2001) Genomic change and gene silencing in polyploids. Trends in Genetics 17: 675-677.

POSTLETHWAIT JH, Y-L YAN, MA GATES, S HORNE, A AMORES, A BROWNLIE, A DONOVAN,ES EGAN, A. FORCE, Z. GONG, C. GOUTEL, A. FRITZ, R. KELSH ET AL. (1998) Vertebrate genome evolution and the zebrafish gene map. Nature Genetics 18: 345-349. 
RAFF RA (1996) The shape of life: genes, development, and the evolution of animal form. University of Chicago Press, Chicago, Illinois, USA. $520 \mathrm{pp}$.

RAVI J, M RIVERA \& J LAKE (1999) Horizontal gene transfer among genomes: the complexity hypothesis. Proceedings of the National Academy of Sciences USA 96: 3801-3806.

RICE WRR \& EE HOSTERT (1993) Laboratory experiments on speciation: what have we learned in 40 years? Evolution 47: 1637-1653.

ROKAS A, \& PWH HOLLAND (2000) Rare genomic changes as a tool for phylogenetics. Trends in Ecology and Evolution 15: 454-459.

ROSENBERG SM (2001) Evolving responsively: adaptive mutation. Nature Reviews Genetics 2: 504-515.

ROTH G, KC NISHIKAWA \& D WAKE (1997) Genome size, secondary simplification, and the evolution of the brain of salamanders. Brain Behavior and Evolution 50: 50-59.

RUDDLE FH (1997) Vertebrate genome evolution - The decade ahead. Genomics 46: 171-173.

RUIZ IRG \& O BRISON (1989) Methylation of ribosomal cistrons in diploid and tetraploid Odontophrinus americanus (Amphibia, Anura). Chromosoma 98: 86-92.

SCHLOSSER G \& D THIEFFRY (2000) Modularity in development and evolution. Bioessays 22: 1043-1045.

SCHMIDTKE J, W BEÇAK \&W ENGEL (1976) The reduction of genic activity in the tetraploid amphibian Odontophrynus americanus is not due to loss of ribosomal DNA. Experientia 32: 27-28.

SEOIGHE C \& KH WOLFE (1999) Yeast genome evolution in the post-genome era. Current Opinion in Microbiology 2: 548-554.

SHARMAN AC \& PWH HOLLAND (1998) Estimation of Hox cluster number in lampreys. International Journal of Developmental Biology 42: 617-620

SHARMAN AC, A HAY-SMITH \& PWH HOLLAND (1997) Cloning and analysis of an HMG gene from the lamprey Lampetra fluviatilis: gene duplication in vertebrate evolution. Gene 184: 99-105.

SESSIONS SK \& A LARSON (1987) Developmental correlates of genome size in plethodontid salamanders and their implications for genome evolution. Evolution 41: 1239-1251.

SOLTIS DE \& PS SOLTIS (1995) The dynamic nature of polyploid genomes. Proceedings of the National Academy of Sciences USA 92: 8089-8091.

SOLTIS DE \& PS SOLTIS (1999) Polyploidy: recurrent formation and genome evolution. Trends in Ecology and Evolution 14: 348-352.
SONG K, P LU, K TANG \& TC OSBORN (1995) Rapid genome change in synthetic polyploids in Brassica and its implications for polyploid evolution. Proceedings of the National Academy of Sciences USA 92: 7719-7723.

SPARROW AH \& AF NAUMAN (1976) Evolution of genome size by DNA doubling. Science 192: 524-529.

SPRING J (1997) Vertebrate evolution by interpecific hybridization - are we polyploid? Federation of European Biochemical Societies 400: 2-8.

SPRING J (2003) Major transitions in evolution by genome fusions: from prokaryotes to eukaryotes, metazoans, bilaterians and vertebrates. Journal of Structural and Functional Genomics 3: 10-25.

STÖCK M, DK LAMATSCH, C STEINLEIN, JT EPPLEN, W-R GROSSE, $\mathrm{R}$ STOCK, $\mathrm{T}$. KLAPPERSTÜCK, KP LAMPERT, U SCHEER, M SCMID \& M SCHARTL (2002) A bisexually reproducing all-triploid vertebrate. Nature Genetics 30: 325-328.

TYMOWSKA J (1991) Polyploidy and cytogenetic variation in frogs of the genus Xenopus. In: Green DM \& SK Sessions (eds) Amphibian cytogenetics and evolution: 259-297. Academic Press, New York, New York, USA.

VENCES M, G APREA, T CAPRIGLIONE, F ANDRONE \& G ODIERNA (2002) Ancient tetraploidy and slow molecular evolution in evolution of Scaphiophryne: ecological correlates of speciation mode in Malagasy relict amphibians. Chromosome Research 10: 127-136.

VINOGRADOV AE, LJ BROKIN, R GÜNTHER \& JM ROSANOV (1990) Genome elimination in diploid and triploid Rana esculenta males: cytological evidence from DNA flow cytometry. Genome 33: 619-627.

WALLIS M, A LIOUPIS \& OC WALLIS (1998) Duplicate growth hormone in sheep and goat. Journal of Molecular Endocrinology 21: 1-5.

WENDEL JF (2000) Genome evolution in polyploids. Plant Molecular Biology 42: 225-249.

WOESE K (1987) Bacterial evolution. Microbiological Reviews 51: 221-271.

WOLFE KH (2001) Yesterday's polyploids and the mystery of diploidization. Nature Reviews, Genetics 2: 333-341.

WOLFE KH \& WH LI (2003) Molecular evolution meets the genomics revolution. Nature Genetics Supplement 33:255-265.

ZHANG J (2003) Evolution by gene duplication: an update. Trends in Ecology and Evolution 18: 292-298. 